\title{
Self Directed Learning and Other Learning Strategies to Learn English Language
}

\author{
B V Ramani, \\ Asst. Professor, GVP College of engineering for women, Visakhapatnam
}

\section{Introduction}

This paper emphasizes the Self Directed learning Strategy which is an effective language learning strategy as $21^{\text {st }}$ century society is an increasingly complex, diversified, globalized and media-centered with a plethora of opportunities. To meet its standards, $21^{\text {st }}$ century language learner should have the knowledge of diversified fields. Apart from these, the student as well as the teacher should focus on language learning strategies since English language has become a tool in every field of learning. Language learning strategies are not newly created but have been in use thousands since many years. Research shows different language learning strategies such as Cognitive, Meta-Cognitive, Guided, Compensation, Social, Affective and self directed etc. It is not an easy task for teachers to accommodate different learning styles unless the students develop the skill to shift learning styles according to the activity, situation and the need of the day. In order to be an effective learner, one could adopt the self directed learning strategy by which the student hones the language learning skills.

The following brief description of language learning strategies could enable the learner to adopt suitable strategy to acquire language skills.

\subsubsection{Cognitive strategy}

Cognitive Strategy is, using mind skills in learning. This is, another effective language learning strategy, by which the learner exercises cognitive skills such as memorizing, visualizing, revising, reflecting and relating etc. Cognitive strategy helps the learner to use mind maps, get clues in reading and to scan the text. The learner could monitor and self-test the grammatical accuracy, originality and consistency. By reducing mother tongue influence, the learner could acquire high language proficiency i.e. the learner should start thinking in targeted language (English) before expressing the ideas.

\subsubsection{Meta-Cognitive strategy}

Meta-Cognitive is, higher-order thinking that enables understanding, analysis and control of one's cognitive processes, especially when engaged in learning. In other words, it is an analysis and nurturing of one's own cognitive skills. A learner analyzes the mind skills i.e. at what level his understanding, memory, reflection and thought process stand. A teacher models different strategies for learners by motivating them to understand, plan and prepare to exercise language learning skills. By this, a student learns to prioritize, sort out the goals and successfully meet different obligations and commitments.

\subsubsection{Guided Learning Strategy}

Guided learning is, the teacher helps the student in analyzing and synthesizing new concepts. There is an ample scope for the student to exercise the core skills such as problem solving and critical thinking. A learner could understand the concept clearly and deeply. The application and sharing of the knowledge is possible. The learner after being comfortable with new concepts and skills, feel free to participate in group activities and could progress in learning the language. The learner comprehends the procedures, outcomes and expectations related to their assignments and tasks. Learning, Speaking, Reading and Writing skills can be practiced.

\subsubsection{Social Strategy}

Society also involves in language learning. Language is used in communication and communication occurs between people. Social strategies help the learner to improve their language as it provides more scope for communication. While communicating, a learner has to face different situations and use different expressions. A learner with serious commitment and strong desire to communicate in English, practice the language and succeed. 


\subsubsection{Affective Strategy}

Affective strategy helps the learner to overcome negative emotions such as nervousness, frustration, low self-esteem, insecurity and attitude which hinder the learning process. The learner becomes conscious about the teacher and the peer group (drawn from the student body itself) while performing the task. The learner could successfully regulate emotions, anxiety and attitude by meditating, listening to music and by self-encouragement before performing the activity that was given by the teacher.

\subsubsection{Compensation Strategy}

Compensation strategy helps all levels of learners who do not have command over language. Guessing helps the learner to recollect past experience and relate that to the context and understand the meaning clearly. The learner could compensate the word by another word by guessing. The teacher, by using other clues such as audio/video/images enable the student to tryout the meaning of the words. By this, the learner could overcome the limitations in speaking and writing.

\subsection{Self Directed Learning Strategy}

Self directed learning has different meanings. It may be different to different people, in different disciplines and in different cultures. Therefore, it is very important to explain the concept of independent learning. The following definition clearly places the responsibility for learning in higher education and the students must be aided by teaching staff and the limits and objectives of the learning program must be defined. Philip Candy, the Deputy Vice Chancellor at the University of Southern Queensland, in his classic text "Selfdirection for lifelong learning" (1991, p 13), quotes Forster (1972, p ii) while defining independent learning/study.

1) "Independent study is a process, a method and a philosophy of education: in which a student acquires knowledge by his or her own efforts and develops the ability for inquiry and critical evaluation;

2) it includes freedom of choice in determining those objectives, within the limits of a given project or program and with the aid of a faculty advisor;

3) it requires freedom of process to carry out the objectives;

4) it places increased educational responsibility of the student for achieving the objectives and for the value of the goals".

Self directed learning is one of the most effective and suitable strategies which could be adopted by the $21^{\text {st }}$ century language learner. It enables the learner to decide when, where, what and how to use the language. The learner designs the plan and method to be followed to learn/master the language under the guidance of the teacher and also by using the internet. In self-directed learning, libraries and companions too play a pivotal role as the learner refers to the books and perceive the ideas of the companions. It can be perfectly done at university level as the learner could plan, study and analyze the complex ideas and concepts. But a $21^{\text {st }}$ century learner could start independent learning at secondary education level. So that both cognitive and meta-cognitive skills can be fruitfully exercised.

1.2.1 Sheerin's (1997:57) model, cited by Andrew Morall, an English teacher in Hong Kong Polytechnic University, in "An Investigation into Learner's Disposition and Perceived Ability to Learn Independently in the centre for Independent Language Learning" explains the activities involved in independent learning that illustrates the range of factors from dependence to independence. This model allows learners to analyze one's own strengths and weaknesses and to understand language needs. To analyze these, learners are provided with explanation and framework. It also provides links to various tests and authentic communication situations so that, language learner could evaluate his/her progress.

Language enables a person to access the other fields of knowledge. So, the learner's goal is essentially, to acquire language skills. Independent learning strategy helps the learner to decide suitable methods of learning and level of competence that could be aimed for. A non-native speaker of English encounters lot of problems while interaction, writing letters, sending mails, discussions and during conferences. These all can be slowly and successfully eliminated by self talk and constant self-analysis. Targeted language videos and audios could serve the purpose of the learner to a great extent.

As discussed earlier, self directed learning involves the peer group as well as the teacher, the learner could learn the nuances of language by taking clues from peer group and by the teacher's instruction. While performing a group activity, being a participant, he/she has to play a positive role and contribute something to the group's progress. The teacher monitors and evaluates the performance of the group. Evaluation of each participant must be done by the teacher as well as the peer group. The teacher explains the parameters of evaluation and guides the students to understand the term "quality feedback". By this, a learner evaluates other's progress and relates the evaluation process to his own progress. The quality feedback of the teacher and the peer group helps the learner in eliminating the negative emotions and could successfully acquire language skills. This 
sort of evaluation process gives scope to evaluate one's own positives and negatives. So, participation in group activities is itself a self training and self motivation.

\section{Conclusion}

The critics expressed many doubts against self directed learning strategy as they doubt the individual's ability to learn. But, for the $21^{\text {st }}$ century learners this strategy is suitable to meet its standards and to reach the expectations of the parents and the teachers. The student could achieve the objectives by using various sources accessible to him/her, such as communication, teachers, peer group, library and internet. Language learners use all the above mentioned learning strategies either consciously or unconsciously in learning process. They are inseparable and invoke life skills which are latent in everyone.

\section{References}

[1]. Stella Hurd, Tim Lewis. “Language Learning Strategies in Independent Settings.” Multilingual Matters.2008. Web.15.June .2013.

[2]. Michael Lessard-Clouston.” Language Learning Strategies: An overview for L2 Teachers: First published in Essays Languages and Literatures," 8, at Kwansei Gukuin University, December ,1997.web.14,15 June. 2013.

[3]. Candy, P. "Self Direction for Life Long Learning: A Comprehensive Guide to Theory and Practice." Sanfransisco. Jossey Bass,(1991)Web. 16, 17 June.2013

[4]. Andrew J. Morrall. "An Investigation Into Learner's Disposition and Perceived Ability to Learn Independently in the Centre for Independent Language Learning”. Hong Kong Polytechnic University in January 1998.web.16 June. 2013. 